\title{
Agro-food Regulatory Harmonization in the Argentine Republic, Local Challenges and Integration: The Mercosur Case
}

\author{
González Acosta Gustavo \\ Universidad Nacional de Lomas de Zamora, Buenos Aires, Argentina
}

\begin{abstract}
The process of the agri-food chain reflected in the well-known expression "from farm to fork" is not always carried out in the same country, but in different countries that develop their relationship in different territories and consequently could be subject to the law of any of them. Therefore, the need arises for a common system of standards. In the case of the Argentine Republic, for example, Mercosur, through the Economic Complementarity Agreements, the partial scope agreements and the decisions of the Common Market Group are established as obligatory sources. The challenge of achieving the constitution of a Common Market of the South that harmonizes agri-food norms, among others, in a true system of regional integration, we believe, is in the making, there are still no supranational authorities of an administrative nature, parliamentary (operational) and judicial that allow the operative application of the harmonization norms.
\end{abstract}

Keywords: harmonization, agri-food, integration, Mercosur

\section{Introduction}

As Amat Llombart (2015) stated:

The process of the agri-food chain begins, therefore, in the primary link of food production by the farmer, to reach its culmination in the distribution and commercialization phase of the food product to the final consumer, a process that is well reflected in the well-known expression "from farm to fork", it is not always carried out in the same country, but in many cases, they are transactions in which the participation of agents is frequent, different countries that develop their relationship in different territories and consequently could be subject to the law of any of them.

For Bonilla Aldana (2018), in turn,

the difficulty in determining the regime applicable to the commercial relationship and the lack of a solution to this problem, which is in line with the requirements of international trade and the needs of market agents, they constitute a situation that is not very beneficial for the merchants. They will have to be subject to the uncertainty of ignorance of the regime applicable to the relationship and the increase in transaction costs as a consequence of the need to avoid possible negative effects in the future.

Therefore, the need arises for a common system of international standards that favorable for the countries that are part of several selective systems, in our case, the Argentine Republic and Mercosur.

The purpose of this paper is to analyze different doctrinal and normative criteria related to the harmonization of food and agriculture regulations in the Argentine Republic, local challenges, and integration

Gonzalez Acosta Gustavo, Doctor of Law, titular professor, Faculty of Law, Universidad Nacional de Lomas de Zamora, Buenos Aires, Argentina. 
processes: The case of Mercosur.

\section{Concept of Harmonization}

Although we have not found an unique conceptualization of the harmonization of law, very authors have sketched different definitions; thus, Bodgan (2006) defined it as "making compatible the provisions of two or more systems" (p. 30). And finally, Rodriguez (2007) affirmed that

by the normative harmonization we refer to the procedures that suppose a modification of the legislation of several States without reaching a complete unification, but with the purpose of creating an essential affinity between several legislations, either of substantive type or of adjective or procedural type. (p. 113)

It is important to point out that the harmonization of the law is not aimed at the elimination of all the differences between legal systems, but tends to suppress the substantial or procedural differences that block the development of international trade.

\section{Internal Norms and Food Competition in the Argentine Republic}

In agro-alimentary matter (including the sanitary matter), it is the problematical one of the demarcation of competitions in a federal system of government, as it is the case of the Argentine Republic, specially between the nation, the provinces, and the autonomous city of Buenos Aires which is of special relevance. The basis of the discussion was based on the applicable constitutional norms.

Bidart Campos (2004) already pointed out, referring to

the planning, ordering and provision of services, (applicable, we understand, to the theme developed here, by virtue of those established in relation to the public health care service provided in Law 27,233). Has aroused for some time, like other analogous problems in which the distribution of power between the federal state and the provinces-the controversy of centralist and federalist positions. (p. 735)

In this controversy which continues now, as if will be observed in the cases analyzed below, the federal competence for the National Congress to legislate could be based on different constitutional norms.

We will begin, on the one hand, with the so-called "progress clause", current Article 75 inc. 18 of the Magna Letter, completed-after the reform of 1994 by subsection 19 below-and, on the other hand, the "commercial clause", contained in Article 75 inc. $13 .{ }^{1}$

The "clause of progress" cited has its counterpart in that contained in Article 125 of the National Constitution that sets similar powers at the head of the provinces ${ }^{2}$.

On the other hand, in order to justify local competences, it must not be forgotten that our state; according

\footnotetext{
${ }^{1}$ Article 75 C.N: "Corresponds to the Congress: Inc. 13: Regulating Trade with Foreign Nations and of the provinces among themselves ... Inc.18: Providing what is conducive to the prosperity of the country, to the advancement and welfare of all the provinces and the progress of the illustration, dictating plans of general education and university, and promoting industry, immigration, the construction of railways and canals navigable land, the colonization of nationally owned land, the introduction and establishment of new industries, the importation of foreign capital and the exploration of inland rivers, protective laws of these ends and by temporary concessions of privileges and rewards".

${ }^{2}$ Said norm establishes: Article 125: "The Provinces may conclude partial treaties for purposes of administration of justice, economic interests and works of common utility, with knowledge of the Federal Congress; and promote industry, immigration, the construction of railways and canals navigable land, the colonization of provincially owned land, the introduction and establishment of new industries, the importation of foreign capital and the exploration of their rivers, by laws protective of these ends and with their own resources. The Provinces and the city of Buenos Aires can keep Social Security agencies for public and professional employees; and promote the economic progress, human development, employment generation, education, science, knowledge and culture".
} 
to the adopted constitutional model, it is a territorial-based organization, composed of provinces and municipalities, as partial arrangements of the primary or original structure, to which it recognizes sovereignty in the first level of state powers. Because it is a federal system, the provinces retain all the power not delegated in the central government; they give their own local institutions and are governed by them (Articles 1, 121, and 122 of the National Constitution).

After the reform of 1994, Article 42, third paragraph of the National Constitution-which prescribes-must also be cited as applicable to the subject under analysis: ... In addition, Art. 75 Paragraph 19 of the National Constitution establishes that

It corresponds to the Congress: To provide what is conducive to human development, economic progress with social justice, to the productivity of the national economy, to the generation of employment, to the professional training of workers, to the defense of the value of currency, research and scientific and technological development, its dissemination and use. To provide for the harmonious growth of the Nation and the settlement of its territory; promote differentiated policies that tend to balance the unequal relative development of provinces and regions.

We understand, for the purposes of this paper, that the regulation of the productivity of the national economy that is a power delegated by the provinces to the nation would include agri-food production processes, with the development scope of the present.

The Decree-Law 18.248 declares valid throughout the territory of the Republic, with the denomination of Argentine Food Code ${ }^{3}$, hygienic-sanitary, bromatological, and commercial identification standards of the Food Regulation approved by Decree 141/53, with its amendments and complementary rules.

This Code and its complementary provisions are applied and enforced by the health authorities, national, provincial or of the Autonomous City of Buenos Aires, in their respective jurisdictions, without prejudice to the verification of their hygienic-sanitary, bromatological, and commercial identification conditions in the jurisdiction of destination ${ }^{4}$.

However, the local character of the exercise of the police function as it arises from the National Constitution, by express legal provision, a concurrent competence is foreseen, between the local authority and the national authority; the latter is able to "concur to enforce said norms in any part of the country".

The technological advance used in the preparation of food can vary dramatically. Thus, a manufacturing process may not appear in the AFC, even implicitly; in this case, if food does not introduce strange or undesirable elements, or does not alter the nutritional value or bromatological aptitude of the finished foods, it is considered lawful ${ }^{6}$.

\section{Import and Export of Food}

When the food is imported, the requirements of the AFC will be applied ${ }^{7}$, being at the discretion of the application authority the consideration of satisfied the legal requirements of the AFC, when the products come from countries that have levels of food control comparable to those of the Republic Argentina, or when the Codex Alimentarius ${ }^{8}$ standards are used.

\footnotetext{
${ }^{3}$ Hereinafter: AFC.

${ }_{5}^{4}$ Arts. 1, 2, y 3 del AFC.

5 Art. 2, in fine del AFC.

6 Resolución Conjunta SAGPyA; SP y RS No. 187; No. 48; 04.05.00.

7 Decree. ME and SAyA 2092; 10.10.91 substitutive of Art. 2 of Decree 2126/71.

${ }^{8} \mathrm{FAO} / \mathrm{WHO}$.
} 
In the cases of imports from countries where economic integration agreements or reciprocity agreements apply, the requirements of the AFC may be considered satisfied, after evaluating the food control system in each country of origin.

Regarding the export of food, exporters are entitled to comply with the requirements of the CAA or those that apply in the country of destination, at their sole option.

\section{Mercosur}

Mercosur, as an open and dynamic process, since its creation, had as main objective to promote a common space that would generate commercial and investment opportunities through the competitive integration of national economies into the international market.

According to the provisions of Article 1 of the (suppress) Ouro Preto Protocol, ${ }^{9}$ Mercosur's intergovernmental decision-making bodies are: the Common Market Council, the Common Market Group, and the Mercosur Trade Commission.

\section{Common Market Council (CMC)}

The Common Market Council is the top organism of Mercosur which is responsible for the political management of the integration process and decision-making to ensure compliance with the objectives established by the Treaty of Asunción and to achieve the final constitution of the Common Market. To fulfill its functions, the $\mathrm{CMC}$ has dependent bodies or forums, such as: the Permanent Representatives Commission of Mercosur, Meetings of Ministers, High Level Groups, among others.

It is pronounced by decisions, which are mandatory for the states parties.

\section{Common Market Group (GMC)}

Common Market Group is the executive organ of Mercosur. Decision CMC No. $12 / 12^{10}$ established the current structure dependent on the Common Market Group ${ }^{11}$.

This technical regulation applies to Nutritional Information Complementary ${ }^{12}$ NIC contained in the labels, of the packaged foods that are produce and market in the territory of the states parties Mercosur, to the trade between them and extra-zone imports, packaged in the absence of the customer, ready to offer them to consumers, as well as, even those contained in advertisements in the media and in all messages transmitted orally or in writing, of foods that are marketed ready for the offer to the consumer.

Exceptions are food for special purposes (as defined in the RTM on the labeling of packaged foods); mineral waters, and other packaged waters intended for human consumption; and to table salt; without prejudice to the provisions of the specific technical regulations ${ }^{13}$.

\section{Contents of the Nutrition Claims}

The regulation defines NIC as:

Any representation that affirms, suggests or implies that a food has particular nutritional properties, especially, but not

\footnotetext{
9 Additional Protocol to the Treaty of Asunción on the Institutional Structure of MERCOSUR (Protocol of Ouro Preto).

10 See http://www.mercosur.int/innovaportal/file/3878/1/dec_012-2012_es_tipologia_y_estructura.pdf.

11 Saw. Resolution No. 01/12 Mercosur/GMC Technical Regulation Mercosur on Complementary Nutritional Information (INC).

12 See http://www.puntofocal.gov.ar/notific_otros_miembros/pry33a1_t.pdf.

${ }^{13}$ Art. 2.1 of the Regulation.
} 
only, in relation to its energy value and/or its content of proteins, fats, carbohydrates and dietary fiber as with its content of vitamins and minerals.

By express regulation, the declarations of properties relative to the content of nutrients (absolute content) are the NIC that describes the level and/or quantity of one or more nutrients and/or energy value contained in the food ${ }^{14}$.

The (suppress) Declaration of Comparative Properties (Comparative Content): It is the INC that compares the levels of nutrient/s and/or the energy value of the food object of the same with the reference food.

\section{Authorized Terms for Complementary Nutritional Information}

In relation to the terms authorized for the NIC, it is established ${ }^{15}$ that it must be written in the official language of the country of consumption (Spanish or Portuguese), without prejudice to the existence of texts in other languages. In cases where there are texts in other languages related to the (suppress) NIC that do not comply with the provisions of this regulation, these should not be visible on the label.

However, there are some terms in English authorized for the respective languages, which do not need to be translated.

\section{Economic Complementation Agreement No. 18}

The purpose of this Agreement is to facilitate the creation of the necessary conditions for the establishment of the Common Market to be established (suppress ) in accordance with the Treaty of Asunción dated March 26, 1991, the main instruments of which, during the transition period, except for its application to the Agreements of Partial Scope, of Economic Complementation Numbers 1, 2, 13, and 14, nor to the commercial and agricultural agreements, subscribed in the framework of the Treaty of Montevideo 1980.

\section{Regulations of Origin of Products in the Common Market of the South}

This regulation defines the rules of origin of Mercosur, the provisions, and administrative decisions to be applied by the state parties for the purposes of: (a) qualification and determination of the originating product; (b) issuance of certificates of origin; and (c) sanctions for adulteration or falsification of certificates of origin or for non-compliance with the verification and control processes.

\section{Extra-Mercosur Mode}

Under the current regime, a modality of cooperation called "Extra-Mercosur" is contemplated, with the establishment of priorities for such cooperation. Thus, the Common Market Group approved by means of Decision CMC No. 23/14 established different priority areas to which they must contribute the cooperation projects directed to Mercosur.

\section{Conclusion}

The lack of reliable knowledge about the legal regime applicable to an international agri-food transaction is one of the main reasons that discourage foreign investment and world trade, which has led the doctrine to affirm that one of the main objectives of the legislator should be to obtain predictability and stability in

\footnotetext{
14 Art. 2.1.1.1 of the Regulation.

15 Art. Por 2.1.1.2 of the Regulation.
} 
business relationships.

In the Argentine Republic, Decree-Law 18.248 declares in force throughout the territory of the Republic, with the denomination of Argentine Food Code, hygienic-sanitary, bromatological, and commercial identification standards of the Food Regulation. The same and its complementary provisions are applied and enforced by the health authorities, national, provincial, or of the autonomous city of Buenos Aires, in their respective jurisdictions.

Regarding the export of food, the AFC contemplates the attribution of the exporters to opt for the fulfillment of the requirements of the AFC or those that govern in the country of destination, at their sole option. When the food is imported ${ }^{16}$, it is application authority at the discretion of the consideration of satisfied the legal requirements of the AFC, when the products come from countries that have levels of food control comparable to those of the Argentine Republic, or when the standards are used of the Codex Alimentarius.

In Mercosur, the Economic Complementarity Agreements, the partial scope Agreements and the decisions of the CMG are established as binding sources of Law for the Parties, including those of an agri-food nature, which make the states parties internationally responsible for the incorporation of the internal law is carried out through administrative decisions.

The challenge of achieving the constitution of a Common Market of the South that harmonizes agri-food standards in a true Regional Integration System, we believe, is in the making, there are still no supranational authorities of an administrative, parliamentary (operational), and judicial nature that allow the operational application of the harmonization rules.

\section{References}

Amat Llombart, P. (2015). Problems of functioning of the agri-food chain in the European Union and in Spain: Deficits to eradicate and improvable aspects. Iberoamerican Magazine of Agrarian Law August 2015, Number 2. Retrieved from http://www.ijeditores.com.ar/pop.php?option=articulo\&Hash=fba2216e77dc89697aa22df387b7aeac

Bidart Campos, G. (2004). Federal jurisdiction and provincial jurisdiction in electroenergetics. El Derecho, Supplement. Number 8. Buenos Aires.

Bodgan, M. (2006). Making the legal rules of two or more legal systems more alike (free translation). Comparative Law (1st ed.). London: Springer.

Bonilla Aldana, J. (2018). Harmonisation of law, concept and critics with regard to its implementation. Retrieved from http://revistas.uexternado.edu.co/index.php/emerca/article/view/3749/3943

González Acosta, G. (2019). Manual de derecho agroalimentario argentino. Buenos Aires: Ediciones Jurídicas.

Pastorino, L. (2011). Derecho Agrario argentino. (2da edición actualizada). Buenos Aires: Abeledo Perrot.

Rodriguez, M. (2007). Armonización legislativa en materia de salvataje de empresas en el Mercosur. Una quimera o una necesidad? (Tesis doctoral, Universidad de Buenos Aires).

${ }^{16}$ Decree ME and SAyA 2092; 10.10.91 substitutive of Art. 2 of Decree 2126/71. 